The present study suggests that these objective methods, especially with the addition of $\beta$-blockade, could be used to measure the rate of desensitization produced by the portrayal of violence on television and in films. It is, perhaps, optimistic to expect that this vagally mediated aversion to violence can be allowed to decrease in the population without socially harmful effects becoming apparent. Being "sick to the heart" with violence may be one of the most effective and necessary forces in restraining man's innate tendency to aggression.

The studies on television watchers were made possible by the kind help of Dr. Effron Gwynne-Jones, of the Further Education Department of the B.B.C. CIBA Company provided financial assistance and some of the volunteers for the studies on film viewing. Our thanks are also due to the Medical Research Council for providing the AutoAnalyzer on which the analyses were performed, and to Professor Norman Ashton for laboratory facilities while M.C. was at the Institute of Ophthalmology. Miss Eileen Willmott provided valuable technical help and Mr. Brian Augier analysed the results. We are grateful to members of the Audio-Visual Department of Moorfields Eye Hospital for use of their television replay facilities. Mr. David Gibbons provided skilled help with the E.C.G. techniques and constructed the switching boxes for the E.C.G. recorders.

Reprints may be obtained from Dr. M. Carruthers, Department of Chemical Pathology (Research), St. Mary's Hospital Medical School, London W2 1 PG.

\section{References}

B.B.C. Audience Research Department (1972). Violence on Television: Programme Content and Viewer Perception. London, British Broadcasting Corporation.

British Medical fournal, 1973, 2, 565.

Cannon, W. B. (1929). Bodily Changes in Pain, Hunger, Fear and Rage, 2nd edn. New York, Appleton.

Carruthers, M. E. (1973). The Western Way of Death. London, Davis-

Poynter. In press.
Carruthers, M. E., Taggart, P., and Somerville, W. (1973). In New Perspectives in $\beta$-Blockade, ed. D. M. Burley, J. H. Frier, R. K. Rondel, spectives in $\beta$-Blockade, ed. D. M. Burley, J. H. Frier,
and S. H. Taylor, p. 307. Horsham, Ciba Laboratories.

Davidson, P. O., and Hiebert, S. F. (1971). Fournal of Abnormal Psychology, 78, 154.

Edmondson, H. D., Roscoe, B., and Vickers, M. D. (1972). British Medical fournal, 4, 7 .

Folkins, C. H., Lawson, K. D., Opton, E. M., and Lazarus, R. S. (1968). fournal of Abnormal Psychology, 73, 100.

Halloran, J. D. (1967). Attitude Formation and Change. Leicester University Press.

Hamberg, D. A. (1971). Sir Geoffrey Vickers Lecture. London, Mental Health Research Fund. Quoted by Harrington (1972).

Harrington, J. A. (1972). British Medical fournal 1, 228.

Henderson, A. S., Montgomery, I. M., and Williams, C. L. (1972). Lancet, 1,1111 .

Lancet, $1970,1,460$

Lazcet, 1970, 1, 460. In Emotional Stress, ed. L. Levi, p. 169. Basel, Karger

Lazarus, R. S. (1967). In Emotional Stress, ed. L. Levi, p. 169. Basel, Karger. Disease, ed. L. Levi, p. 190. London, Oxford University Press.

Levi, L. (editor) (1971). In Society, Stress and Disease, p. 466. London, Oxford University Press.

Levi, L. (1972). Acta Medica Scandinavica, Suppl. No. 528.

Obrist, P. A. (1963). Psychosomatic Medicine, 25, 450.

Rollason, W. N. (1964). Electrocardiography for the Anaesthetist. Oxford, Blackwell.

Taggart, P., and Carruthers, M. E. (1971). Lancet, 1, 363.

Taggart, P., and Carruthers, M. E. (1972). Lancet, 2, 256.

\title{
Treatment of Muscle Cramps during Maintenance Haemodialysis
}

\author{
G. R. D. CATTO, F. W. SMITH, M. MACLEOD
}

British Medical fournal, 1973, 3, 389-390

\section{Summary}

The effect of a slowly released oral preparation of sodium chloride (Slow Sodium) on the frequency and severity of muscle cramps, on blood pressure, and on body weight was compared with that of placebo in a double-blind cross-over trial in 19 patients on maintenance haemodialysis for endstage renal failure. A significant reduction in both the frequency and severity of cramps was found while the patients were receiving the sodium chloride preparation and no significant alteration in blood pressure or body weight was detected.

\section{Introduction}

Muscle cramps occur frequently in patients on maintenance haemodialysis (Eady, 1971; Strauch et al., 1971). The aetio$\operatorname{logy}$ of the condition is not definitely established. Acute oxygen deficiency in metabolically active muscles is considered to be one factor (Chillar and Desforges, 1972). There

University Department of Medicine, Aberdeen AB9 2ZD

G. R. D. CATTO, M.B., M.R.C.P., Research Fellow

M. MACLEOD, M.D., F.R.C.P., Reader in Medicine

Medical Renal Unit, Aberdeen Royal Infirmary, Aberdeen AB9 2ZD F. W. SMITH, M.B., CH.B., Registrar is evidence that a reduction in circulating plasma volume with cellular overhydration is another important aetiological cause (Stewart et al., 1972). It has been noted both in this unit and elsewhere (Gotloib and Servadio, 1972) that intravenous injection of $10-20 \mathrm{ml} 22.5 \%$ sodium chloride solution rapidly relieves muscle cramps. It was decided, therefore, to assess the value of a slowly released oral preparation of sodium chloride (Slow Sodium) as a prophylactic measure. The effect of Slow Sodium on the frequency and intensity of muscle cramps, on blood pressure, and on body weight was compared with that of placebo in a double-blind cross-over trial in patients on regular haemodialysis.

\section{Patients and Methods}

Nineteen patients on maintenance haemodialysis (12 men, 7 women) were admitted to the trial. One patient taking the placebo died from acute bacterial endocanditis and another was withdrawn from the trial while receiving the sodium chloride preparation. Tablets of Slow Sodium contain 600 mg sodium chloride (equivalent to $10 \mathrm{mEq} \mathrm{Na}{ }^{+}$and $\mathrm{Cl}-$ ) prepared in a wax sponge formulation.

Patients were allocated at random to two groups. Patients in the first group were given 14 tablets of Slow Sodium (140 $\mathrm{mEq}$ sodium) during each dialysis for two months followed by 14 placebo tablets during each dialysis for a further two months. The second group received the preparations in the reverse order. Tablets given at each dialysis were administered as follows: 6 tablets half to one hour before starting dialysis, 4 tablets four hours after the start of dialysis, and 4 tablets six hours after the start of dialysis. 
Patients recorded the presence or absence of muscle cramps both during and for two hours after dialysis. To assess the severity of cramps each patient placed a mark on a linear scale from "zero pain" to "infinite pain"; the scale was divided into 10 equal parts and the intensity of pain measured in arbitrary units (thus 1 unit indicated slight discomfort, 10 units severe pain). Body weights and supine and erect blood pressures of each patient were recorded both before and after dialysis.

One patient was dialysed for 10 hours twice a week on a multipoint Kiil dialyser with a surface area of $1 \mathrm{~m}^{2}$, a second was dialysed for 12 hours twice a week, and the remainder were dialysed for 14 hours twice a week on standard Kiil dialysers with the same surface area. A monitored pump dialysate supply (Dylade model B series 3 or Cambridge mark 6A) was used and the sodium concentration of the dialysate was $134 \mathrm{mEq} / 1$.

At the end of the trial the patients were asked which period of therapy they had preferred and their answers were recorded.

\section{Results}

The results obtained from 15 dialyses on a particular treatment were analysed. Two patients reported no cramp during the trial period, and thus table I, showing the incidence of muscle cramps expressed as a percentage of the number of dialyses, is based on data from 15 patients. The administration of Slow Sodium resulted in a statistically significant reduction of $26 \%$ in the frequency $(P<0.05)$ and $30 \%$ in the severity $(P<0.02)$ of muscle cramps.

TABLE I-Frequency and Severity of Muscle Cramps with Slow Sodium and Placebo

\begin{tabular}{|c|c|c|c|}
\hline \multicolumn{2}{|l|}{ Drug } & $\underset{(\%)}{\text { Mean Frequency of Cramps }}$ & $\begin{array}{c}\text { Mean Severity of Cramps } \\
\text { (Units) }\end{array}$ \\
\hline $\begin{array}{l}\text { Placebo } \\
\text { Slow Sodium }\end{array}$ & $\ddot{x}$ & $\begin{array}{l}54 \cdot 7 \\
40 \cdot 7\end{array}$ & $\begin{array}{l}5.4 \\
3.8\end{array}$ \\
\hline
\end{tabular}

No significant differences, however, were detected between Slow Sodium and placebo in the mean systolic or diastolic blood pressure in the erect or supine position either before or after dialysis (table II); nor were significant changes found in the mean body weights before or after dialysis (table III).

Of the 17 patients who completed the trial all remained well; $13(76 \%)$ preferred the sodium chloride preparation, 2 $(12 \%)$ the placebo, and $2(12 \%)$ indicated no preference. This result is significantly in favour of Slow Sodium $(P<0.01)$.

\section{Discussion}

This double-blind placebo controlled cross-over trial shows that Slow Sodium is effective in reducing both the frequency and the severity of muscle cramps in patients on mainten-
TABLE III-Effect of Slow Sodium and Placebo on Mean Predialysis Weight and Mean Weight Loss during Dialysis

\begin{tabular}{ll|c|cc}
\hline \multicolumn{1}{c|}{ Drug } & & $\begin{array}{c}\text { Mean Predialysis Weight } \\
( \pm \text { S.E.) in kg }\end{array}$ & $\begin{array}{c}\text { Mean Postdialysis Weight } \\
( \pm \text { S.E.) in kg }\end{array}$ \\
\hline Placebo & $\cdots$ & $59 \cdot 35 \quad(2 \cdot 27)$ & $57 \cdot 18 \quad(2 \cdot 26)$ \\
Slow Sodium & $\cdots$ & $59 \cdot 45 \quad(2 \cdot 22)$ & $57 \cdot 24 \quad(2 \cdot 23)$ \\
\hline
\end{tabular}

ance haemodialysis. The dose of $140 \mathrm{mEq}$ sodium (14 tablets of Slow Sodium) per dialysis was chosen as it had appeared effective in controlling muscle cramps in some patients before the start of the trial. As the number of tablets required to control cramp may be adjusted to the needs of the individual patient, the procedure is much more appropriate than an increased sodium concentration in the dialysate for all patients (Stewart et al., 1972).

A concentration of about $130 \mathrm{mEq}$ sodium/l. is commonly used in the dialysate to control hypertension and thirst (Moriarty and Parsons, 1966). Stewart et al. (1972) have suggested that hyponatraemia, cellular overhydration, and the consequent reduction in plasma volume due to the low sodium content of the dilysate are important in the pathogenesis of cramp, and they showed a reduction in the frequency of cramps when the sodium concentration of the dialysate was increased to $145 \mathrm{mEq} / \mathrm{l}$. The mode of action of Slow Sodium is probably similar to that of the dialysate with the increased sodium concentration, in that the additional reduction in plasma volume due to hyponatraemia and cellular overhydration is prevented. It is this extra reduction in plasma volume, additional to the more obvious ultrafiltration loss, which is believed to be important in the pathogenesis of muscle cramps.

The tablets, which were administered in the early hours of the dialysis to prevent interruption of sleep, were well tolerated even by those patients usually nauseated by encapsulated sodium chloride preparations.

Clarkson et al. (1971) have shown that in patients with chronic renal failure the sodium chloride content of Slow Sodium tablets is totally absorbed in about six hours. Thus as the last tablets in this trial were taken eight hours before termination of dialysis it is likely that little or no sodium absorption occurred after dialysis. This may explain why these patients, unlike those dialysed against a sodium concentration of $145 \mathrm{mEq} / \mathrm{l}$., neither complained of thirst nor gained excess weight between dialyses.

Hypertension-did not prove to be a problem associated with the administration of Slow Sodium. The patient withdrawn from the trial, a 22-year-old bachelor, had a long history of erratic behaviour and hypertension that was difficult to control adequately; he was not able to keep to a standard diet or to control his fluid intake and his weight gain between dialyses was excessive. Though his blood pressure at the time was no higher than it had been on many previous occasions it was considered that the additional sodium intake was not justified. Slow Sodium did not produce hypertension in those patients with a previously stable blood pressure who maintained a constant postdialysis "ideal" weight.

In this study a significant reduction in both the frequency and severity of muscle cramp was found when the patients

TABLE II-Effect of Slow Sodium and Placebo on Blood Pressure

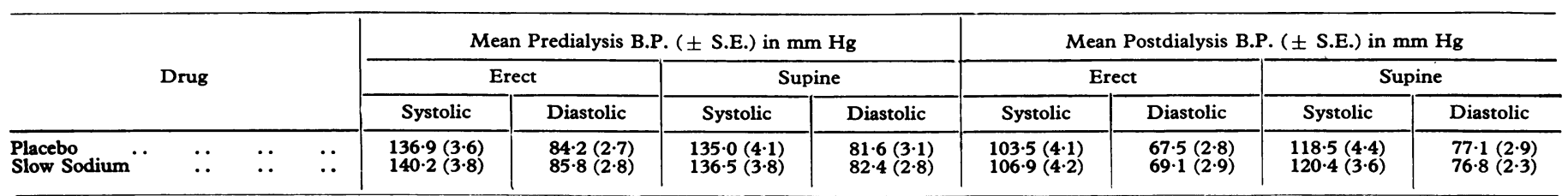


were receiving 14 tablets of Slow Sodium ( $140 \mathrm{mEq}$ sodium) per dialysis. As no alteration in mean blood pressure or body weight was detected it is concluded that Slow Sodium is a useful drug in the prophylaxis of muscle cramps in patients on maintenance haemodialysis for end-stage renal failure.

We wish to thank Mrs. Susan Standen for statistical advice, Ciba pharmaceutical company for the supply of tablets, and the nursing staff of the medical renal unit for their help.

\section{References}

Chillar, R. K., and Desforges, J. F. (1972). Lancet, 2, 285.

Clarkson, E. M., et al. (1971). British Medical fournal, 3, 604

Eady, R. A. J. (1971). Proceedings of Eighth Congress of the European Dialysis and Transplant Association, p. 50. London, Pitman Medical. Gotloib, L., and Servadio, C. (1972). Lancet, 2, 877.

Moriarty, M. V., and Parsons, F. M. (1966). Proceedings of Third Congress of the European Dialysis and Transplant Association, p. 359. London,

Stewart, W. K., Fleming, L. W., and Manuel, M. A. (1972). Lancet, 1, 1049.

Strauch, M., et al. (1971). Proceedings of Eighth Congress of the European Dialysis and Transplant Association, p. 28. London, Pitman Medical.

\section{MEDICAL MEMORANDA}

\section{Symptomatic Hypomagnesaemia after Parathyroidectomy}

\author{
C. T.A. JONES， R. A. SELLWOOD， J. M. EVANSON
}

British Medical fournal, 1973, 3, 391-392

\section{Introduction}

Hypomagnesaemia may occur in a number of clinical situations, including states of malnutrition or malabsorption, after the loss of gastrointestinal secretions by continuous aspiration, in chronic alcoholics, and in primary and secondary aldosteronism. Primary hyperparathyroidism may also be associated with low serum magnesium levels (Harmon, 1956) particularly after parathyroidectomy in those patients with extensive bone disease (King and Stanbury, 1970). In this situation hypocalcaemia and hypomagnesaemia co-exist and this is also common in many of the other low magnesium states, so that it has often proved difficult to attribute the clinical picture to a deficiency of one or other cation.

The present patient with primary hyperparathyroidism and generalized bone disease developed profound hypomagnesaemia and hypocalcaemia after parathyroidectomy. These changes were associated with acroparaesthesiae, muscle weakness, tremor, and mental changes, all of which were reversed by restoration of the serum magnesium level to normal despite a persistently low serum calcium level.

\section{Case Report}

A 67-year-old woman presented with a pathological fracture of the left fermoral neck. There was a five-year history of diffuse bone pains and other symptoms compatible with hypercalcaemia. Radiography showed widespread cystic bone lesions, chondrocalcinosis articularis, and metastatic calcification. The clinical diagnosis of primary hyperparathyroidism was confirmed by the finding of hypercalcaemia $(13.0 \mathrm{mg} / 100 \mathrm{ml})$, hypophosphataemia $(2.2 \mathrm{mg} / 100 \mathrm{ml})$, and a raised level of circulating immunoassayable parathyroid hormone of $30 \mathrm{ng} / \mathrm{ml}$ (normal below $0.5 \mathrm{ng} / \mathrm{ml}$ ).

At operation a benign parathyroid adenoma of chief cell type was excised; the remaining glands appeared macroscopically normal.

University Hospital of South Manchester, Manchester M20 8LR

C. T. A. JONES, M.SC., M.R.C.P., Lecturer in Medicine

R. A. SELLWOOD, CH.M., F.R.C.S., Professor of Surgery

J. M. EVANSON, M.SC., F.R.C.P., Professor of Medicine
Postoperative biochemical changes are shown in the chart. Despite a progressive fall in the serum calcium level, the patient was at first entirely asymptomatic. Oral calcium and vitamin D supplements were started after eight days. On the 10th postoperative day, however, she became strikingly agitated, experiencing episodes of terror and complaining of painful paraesthesiae in the hands and feet. Marked muscle weakness and a generalized fine tremor were observed, but tendon reflexes were nurmal and Chvostek's and Trousseau's signs remained negative. Serum calcium and potassium levels of $6.0 \mathrm{mg} / 100 \mathrm{ml}$ and $3.5 \mathrm{mEq} / 1$ respectively were recorded at this time. Despite regular oral supplements and additional intermittent intravenous infusions of calcium her symptoms worsened.

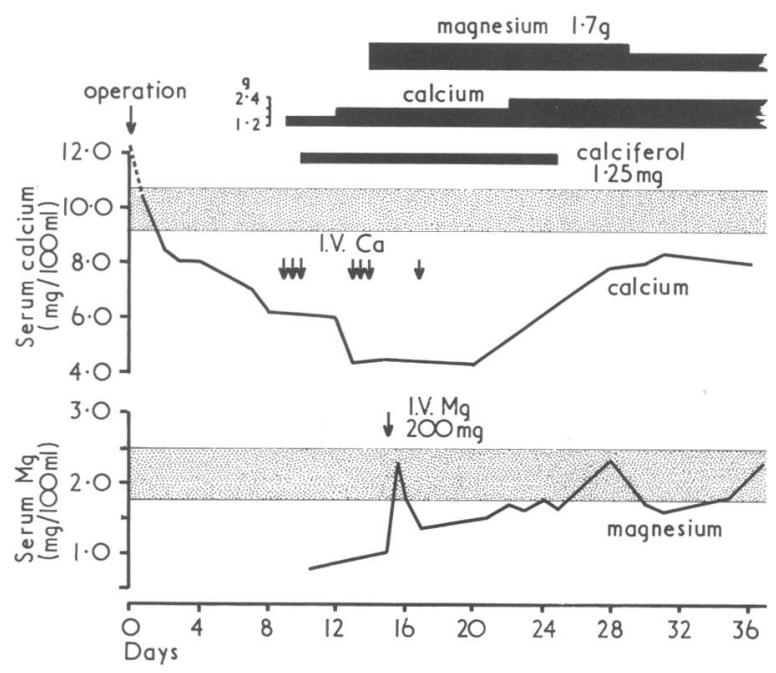

Biochemical changes in patient after operation.

On the 14th day when the clinical picture was most striking, two low serum magnesium levels of 0.7 and $0.9 \mathrm{mg} / 100 \mathrm{ml}$ were recorded at a time when the serum calcium level had reached a nadir at $4.8 \mathrm{mg} / 100 \mathrm{ml}$. An intravenous infusion of $200 \mathrm{mg}$ of elemental magnesium as magensium sulphate in saline was therefore administered over a pericd of two hours. This produced a dramatic symptomatic improvement; the paraesthesiae, tremor and anxiety state lessened and muscle power improved dramatically. Immediately after the infusion, the serum magnesium level had risen to $2.4 \mathrm{mg} / 100 \mathrm{ml}$, the calcium level remaining at $5.5 \mathrm{mg} / 100$ $\mathrm{ml}$. Less severe symptoms had recurred by the next day when she had again become hypomagnesaemic, and oral magnesium as the hydrated oxide (equivalent to $1.7 \mathrm{~g}$ elemental magnesium daily) was therefore started. During the subsequent week, as the serum magnesium level rose towards the normal range, there was a progressive and sustained clinical improvement. No change in the serum calcium level occurred until the 22nd day after surgery at which time the serum magnesium had returned to a low normal value of 1.7 